\title{
DESIGNING AND PILOTING A TOOL FOR THE MEASUREMENT OF THE USE OF PRONUNCIATION LEARNING STRATEGIES
}

\author{
MIROSEAW PAWLAK \\ pawlakmi@amu.edu.pl \\ Adam Mickiewicz University
}

\begin{abstract}
Despite the fact that the last few years have witnessed a growth of interest in pronunciation learning strategies (PLS) (e.g. Petersen 2000; Pawlak 2008a; Wrembel 2008), this line of inquiry still remains neglected and is in urgent need of further empirical investigation. This is because the available research findings are primarily confined to the identification and description of the strategic devices that learners draw upon in their attempts to learn the various segmental and suprasegmental features, with only a handful of studies addressing such issues as the factors influencing PLS choice and use, the impact of proficiency levels or the value of strategies-based instruction in this area. Another problem is related to the use of diverging research methodologies and data collection tools, which renders it impossible to make comparisons between various studies, view their results in a cumulative way and arrive at conclusions concerning the effectiveness of specific strategies used by learners.

What appears to be indispensable to drive the field forward and ensure that research findings will be comparable across studies and provide a sound basis for feasible pedagogic proposals is to draw up a classification of PLS and design on that basis a valid and reliable data collection tool which could be employed to measure the use of these strategies in different groups of learners, correlate it with individual and contextual variables, and appraise the effects of training programs. In accordance with this rationale, the present paper represents an attempt to propose a tentative categorization of pronunciation learning strategies, adopting as a point of reference the existing taxonomies of strategic devices (i.e. O'Malley and Chamot 1990; Oxford 1990) and the instructional options teachers have at their disposal when dealing with elements of this language subsystem (e.g. Kelly 2000; Goodwin 2001). It also introduces a research instrument designed on the basis of the classification that shares a number of characteristics with Oxford's (1990) Strategy Inventory for Language Learning but, in contrast to it, includes both Likert-scale and open-ended items. The findings of a pilot study which involved 80 English Department students demonstrate that although the tool requires considerable refinement, it provides a useful point of departure for future research into PLS.
\end{abstract}

Key words: pronunciation learning strategies, questionnaire development, classification of pronunciation learning strategies 


\section{Introduction}

As Ellis (2008: 703) comments in his latest overview of research in the field of second language acquisition, "The study of learning strategies has been motivated by both the wish to contribute to SLA theory by specifying the contribution that learners can make to L2 learning and by the applied purpose of providing a research-informed basis for helping learners to learn more effectively through identifying strategies that 'work' and training them to make use of those". Over the last thirty years numerous research projects have been undertaken with a view to attaining these goals and it goes without saying that at present we know much more about "activities consciously chosen by learners for the purpose of regulating their own language learning" (Griffiths 2008a: 86) than at the time when the first good language learner studies were conducted in the mid1970s. To name just a few of these accomplishments, there have been successful attempts to establish a link between the application of language learning strategies (LLS) and individual variables (e.g. Reiss 1981; Takeuchi et al. 2007), the use of LLS has been explained in terms of information-processing models (O'Malley and Chamot 1990), and a plethora of classifications of strategic devices have been proposed, often together with accompanying research instruments such as Oxford's (1990) famous Strategy Inventory for Language Learning (SILL) (cf. Anderson 2005; Dörnyei 2005; Grenfell and Macaro 2007; Ellis 2008). Moreover, researchers have recognized the individual and contextual nature of the application of LLS (e.g. McDonough 1995; Cohen 1998), with the effect that more and more emphasis has been placed on the quality rather than only quantity of strategy use (e.g. Macaro 2001), and more elaborate and inventive data-collection tools have been developed (cf. White et al. 2007). Despite all of these achievements, Grenfell and Macaro (2007: 28) conclude that "[...] LLS research is quite an immature field", and, apart from issues involved in defining or establishing distinctive features of strategic devices, one blatant manifestation of this immaturity is the fact that some key areas have barely been tapped by specialists, one of them being the actions and thoughts learners employ in an effort to master various aspects of the pronunciation of the foreign language they are studying (cf. Pawlak 2010a)

The present paper, which builds upon and extends the previous work undertaken by the author (e.g. Pawlak 2006a, 2008, 2010b, in press), represents yet another attempt to grapple with this important issue by proposing a tentative framework for a taxonomy of pronunciation learning strategies (PLS), presenting on that basis a questionnaire for measuring the use of these strategies and reporting the results of a pilot study, the main aim of which was to initiate the process of validating this research instrument. The first part of the paper will be devoted to the discussion of the potential contribution of PLS to learning segmental and suprasegmental pronunciation features as well as the findings of the scant research in this area, with the main focus on the data collection tools employed in particular studies. The second part, in turn, will provide a description of the proposed taxonomy of PLS as well as the data collection tool and discuss insights from the study in which it was utilized. The paper will close with comments on the possible directions of future research addressing pronunciation learning strategies and the methodological considerations involved. 


\section{Contributions of pronunciation learning strategies}

As the present author argues in a previous publication (Pawlak 2006b), given the complexity of foreign language pronunciation as well as the formidable challenge of mastering or merely improving it in foreign language contexts with their scant in- and out-of-class exposure to the target language (TL), a reasonable but also feasible solution is fostering learner autonomy in this respect. This is because this approach " $(\ldots)$ will make students capable of identifying their strengths and weaknesses in this area, setting their own aims, planning and organizing their learning, choosing the most appropriate materials, techniques and learning strategies, and evaluating their own progress" (2006b: 141). Beyond doubt, one of the most important ways in which this vital goal can be accomplished is training students in the use of strategic devices that can be useful in learning and practicing different aspects of pronunciation since adept use of strategies is a key to developing autonomy (Wenden 1991). Extrapolating from the definition of grammar learning strategies provided by Cohen and Pinilla-Herrera (2009), pronunciation learning strategies can be defined as deliberate actions and thoughts that are consciously employed, often in a logical sequence, for learning and gaining greater control over the use of various aspects of pronunciation. What this indicates is that PLS serve the dual function of understanding how target language pronunciation works (e.g. how specific sounds are articulated) and helping them to more successfully deploy segmental and suprasegmental features in spontaneous communication (e.g. making changes typical of fast speech or using the right intonation patterns to convey the intended meaning), which means that they are seen as making a contribution to the development of both explicit, declarative knowledge and implicit, procedural knowledge (cf. Ellis 2005, 2009).

As is the case with the learning of other target language skills and subsystems, it can be assumed that some strategies are more likely to aid the learning of pronunciation features than others. A good point of reference in this connection is the well-known taxonomy proposed by Oxford (1990), in which the main distinction is drawn between strategic devices which are direct (i.e. those which require mental processing of language) and indirect (i.e. those that support learning in general and do not have to involve target language use), with the former being subdivided into memory strategies (used for remembering and retrieving information), cognitive strategies (used to understand and produce language) and compensation strategies (drawn upon to compensate for deficits in existing TL knowledge), and the latter comprising metacognitive strategies (deployed to plan, organize and evaluate the learning process), social strategies (used in learning with others) and affective strategies (applied to regulate feelings and emotions). Common sense as well as the findings of previous research projects (e.g. Petersen 2000, Pawlak 2008a) demonstrate that in the group of direct PLS, it is cognitive strategies, such as naturalistic and formal practice or attempts to analyze the sound system that are likely to play the most significant role, whereas the contribution of memory strategies, such as representing sounds in memory, and compensation strategies, such as using proximal articulations, may be rather limited. When it comes to indirect strategies, since their function is general and they are applicable to learning any aspect of the TL, learners will be unlikely to employ actions or thoughts that would be specific to improving pronunciation. Such strategic devices 
will probably be utilized less frequently than direct ones (cf. Pawlak 2006a, 2008a), with learners opting mainly for metacognitive strategies (e.g. planning for a language task or self-evaluating) rather than social (e.g. asking a classmate to correct one's pronunciation) or affective ones (e.g. encouraging oneself to practice new sounds).

\section{Previous research into pronunciation learning strategies}

Despite the potential inherent in the use of pronunciation learning strategies, until recently they largely remained outside the scope of interest of language learning strategy experts and although the study conducted by Peterson (2000) heralded a welcome change in this respect, ten years later there is still a paucity of empirical investigations specifically targeting PLS (cf. Petersen 2000; Berkil 2009; Pawlak 2010a). Moreover, a closer look at the available research shows that the studies conducted to date have primarily focused on the identification and description of the strategic devices whereas little attention has been given to pinpointing factors affecting PLS choice and use, exploring the relationship between their application and target language attainment, particularly in the area of pronunciation, or determining the effects of strategies-based instruction, both when it comes to the quantity and quality of PLS use and the progress made by learners. Equally disconcerting is the fact that few attempts have been made to come up with specific, comprehensive taxonomies of PLS, with the effect that researchers have elected to approach the study thereof from sometimes quite disparate perspectives and employed very different data collection tools. The consequence of such a situation is that it is exceedingly difficult to make comparisons between the findings of various research projects and, as a consequence, to extend the existing knowledge base concerning the strategic devices learners fall back upon in their attempts to improve their pronunciation. Since the lack of a common theoretical basis and the resultant reliance on diverse data collection instruments appear to be among the most serious woes of PLS research and these issues are also of immediate relevance to our further considerations, the overview of the available empirical investigations provided below will mainly focus upon methodological issues rather than the findings per se, laying special emphasis on the tools selected to gather information about the use of strategies.

Although early research into language learning strategies failed to focus solely on PLS, some studies did look at the steps learners take to enhance their pronunciation learning as part of their evaluation of the overall repertoire of strategic devices they employ. This is evident in the examination of successful language learners conducted by Naiman et al. (1978), where 34 subjects were interviewed, the research project carried out by Rivers (1979), in which she recorded in a diary her experiences in learning Spanish, as well as the study undertaken by O'Malley et al. (1985) who applied their own classification of language learning strategies into metacognitive, cognitive and socioaffective to analyze the techniques utilized by 70 high school ESL students when performing nine oral language tasks. The same taxonomy was drawn upon by DroździałSzelest (1997) who investigated PLS as part of a larger-scale study of the strategies utilized by Polish secondary school learners and employed for that purpose an openended questionnaire for teachers and learners. 
As mentioned above, research focusing exclusively on pronunciation learning strategies was initiated by the study conducted by Petersen (2000) in which she collected data on PLS use from eleven English-speaking learners of Spanish as a foreign language who represented three different proficiency levels (i.e. beginner, intermediate and advanced). The procedures she employed involved the use of self-report, retrospective data collection tools in the form of diaries and interviews while the analysis of the resulting strategies and tactics was conducted by means of Oxford's (1990) descriptive scheme. This seminal study paved the way for other empirical investigations, some of which have gone beyond mere identification or description, attempting to offer tentative classifications of PLS, relating their use to gains in performance, or seeking to explore the effects of PLS training. Vitanova and Miller (2002), for example, carried out an action research study in which they used open-ended prompts to elicit students' reflections on learning pronunciation, qualitative analysis of which pointed to the importance of conscious-raising and metacognitive strategy training. Osborne (2003), in turn, investigated the application of PLS by advanced learners of English by means of monitored interviews and think-aloud protocols while the subjects attempted to monitor and improve their pronunciation performance, with the data collected providing a basis for identifying seven categories of PLS (e.g. focusing on memory and imitation, focusing on individual words, syllables and sounds). More recently, Eckstein (2007) and Berkil (2009) set out to establish a connection between the employment of pronunciation learning strategies and different aspects of pronunciation performance, with both of them succeeding in finding a positive relationship for at least some PLS. The former study is of particular interest here, since Eckstein proposed a classification of strategies and developed an accompanying questionnaire basing on Kolb's (1984) learning construct as well as four stages in the acquisition of pronunciation, and classified PLS into the four main categories: (1) concrete experience - input/practice (e.g. intent listening, practicing new sounds), (2) reflection on observation - noticing/feedback (e.g. self-monitoring, focusing on suprasegmentals), (3) abstract conceptualization - hypothesis forming (e.g. monitoring and eliminating negative interference, finding out about the TL pronunciation), and (4) action based on new conceptualization - hypothesis-testing (e.g. skipping difficult words, rehearsing sounds). Finally, worth mentioning is also the research project conducted by Varasarin (2007) who demonstrated that PLS training leads to increased speaking confidence and intelligibility of Thai learners of English, adopting as a theoretical framework Oxford's (1990) inventory, augmented by Petersen's (2000) findings.

In what should undoubtedly be regarded as a very welcome development, the growth of interest in pronunciation learning strategies has found its reflection in the studies conducted by Polish researchers, with some of them clearly constituting valuable contributions to this important line of inquiry. In one such empirical investigation, Bukowski (2004), taking as a point of reference Oxford's (1990) taxonomy, demonstrated that training first-year college students in the use of metacognitive, social and affective PLS resulted in improved quality of their pronunciation, greater awareness and more positive attitudes. In another study, Wrembel (2008) sought to explore English philology students' opinions on the effectiveness of the PLS introduced in class, to identify the strategic devices which the participants viewed as the most and the least enjoyable, and to elicit other PLS they might draw upon. In order to answer these 
research questions, she designed a strategic pronunciation learning survey which relied on O'Malley et al.'s (1985) categorization and included closed, yes-no, Likert-scale and open-ended items. Of particular interest are also three studies carried out by Pawlak (2006a, 2008, in press) as part of a large-scale research program which aimed at identification, classification and evaluation of PLS, pinpointing influences on their use, and determining the contributions of their training, as they yielded copious data instrumental in devising the taxonomy discussed in the following section. They sought to identify the PLS used by groups of learners of English as a foreign language representing different proficiency levels and employed a variety of data collection tools such as a catalog of strategies which can be applied in learning TL pronunciation taken from the European Language Portfolio for Senior High School Students and Language Learners in Institutions of Higher Education (Pawlak 2006a), a questionnaire containing closedand open-ended questions about steps taken to work on this language subsystem (Pawlak 2008a), and diaries in which the participants were guided by a set of prompts (Pawlak in press).

\section{Developing a taxonomy of pronunciation learning strategies and a data collection tool}

It is the lack of a generally accepted descriptive scheme for classifying PLS as well as major differences in data collection procedures visible in the studies discussed above that provided an impetus for undertaking the challenge of drawing up a taxonomy of such strategic devices and designing on that basis a research instrument that would provide valid and reliable data about their use. Similarly to the present author's proposal for the categorization of grammar learning strategies (cf. Pawlak 2009a, 2010b), this attempt was based on the assumption that a classification of PLS should be, at least in its initial version, general rather than language specific and that it should draw upon both a general taxonomy of language learning strategies, such as one of those mentioned earlier, and an inventory of techniques and procedures used in pronunciation instruction. Accordingly, the points of departure in the construction of such an inventory were as follows: (1) the taxonomy of language learning strategies introduced by Cohen and Dörnyei (2002) which attempts to reconcile Oxford's (1990) and O'Malley and Chamot's (1990) models, (2) modified statements adapted from Oxford's (1990) SILL, (3) the options in teaching pronunciation identified in leading publications devoted to this issue (e.g. Kelly 2000; Goodwin 2001), and (4) the findings of previous research in which a number of techniques and strategies used for learning pronunciation have been identified.

Careful examination of the four sources resulted in the construction of a classification composed of four main groups of pronunciation learning strategies, each of which includes a number of more specific strategic devices, namely:

1) metacognitive $P L S$, such as deciding to focus on particular pronunciation features, looking for opportunities to practice new sounds, recording oneself to self-evaluate one's pronunciation, etc.; 
2) cognitive PLS, such as using phonetic symbols or one's own codes to remember sounds, forming and testing hypotheses about pronunciation rules, noticing similarities and differences between the sound systems of L1 and L2 or other known languages, making use of articulatory descriptions (e.g. charts, diagrams, etc.), memorizing the pronunciation of new words, using color or sound associations, repeating after the teacher or a recording, reading aloud, using rhythmic gestures that accompany speech practice, looking up pronunciation in a dictionary, deliberately using words that are difficult to pronounce in spontaneous communication, etc.;

3) affective PLS, such as using relaxation techniques when encountering problems with pronunciation, rewarding oneself for making progress in phonetics, etc.;

4) social PLS, such as practicing aspects of pronunciation with other students, asking others for correction of pronunciation errors, etc.

As can be seen from these categories, the main difference between this taxonomy and those used in many previous research projects is that, following the approach taken by O'Malley and Chamot (1990), it eliminates the distinction between memory and cognitive strategies, subsuming the former under the latter, and scraps altogether the subcategory of compensation strategies, but at the same time retains the division into social and affective strategies which is recommended by Oxford (1990). Furthermore, the group of cognitive PLS is by far the most elaborate, both with respect to the sheer number of strategic devices and their specificity, which is fully warranted by the fact that it contains actions and thoughts which are directly involved in studying and practicing target language pronunciation, thus constituting the core of the whole classification scheme. What should also be emphasized at this juncture is that the taxonomy should be regarded as tentative and open to modification in response to the findings of further research, such as those resulting from the pilot study reported below, which is one of the reasons why it is not provided here in its entirety.

Imperfect and incomplete as it might be, the taxonomy provided a basis for developing a research instrument for measuring the use of pronunciation learning strategies, which also serves the purpose of gathering information about other PLS that may be used by learners but are not included in any of the four categories. The tool is a questionnaire, referred to as the Pronunciation Learning Strategy Survey (PLSS) which aims to provide both quantitative and qualitative data and consists of the following parts:

1) closed and open-ended items providing background information about the subjects, such as proficiency or educational level, length of target language study, final grade in a pronunciation course, overall end-of-semester grade, selfassessment, importance of pronunciation, access to the target language outside school, etc.;

2) 60 five-point Likert-scale items, where 1 indicates that a given statement does not at all apply to the respondent and 5 signifies that it perfectly describes his or her actions and thoughts, such as I repeat after the recording (tapes, CDs, soundtracks) to improve my pronunciation, I look up the pronunciation of new words in a dictionary or I know my strengths and weaknesses when it comes to pronunciation; the items are divided into four subscales representing metacognitive, cognitive, affective and social PLS and at the end of each there is ample space for comments on the statements in the list; 
3) open-ended items in which the respondents are requested to think of ways of learning pronunciation that have not been included in the survey, describe their favorite ways of studying and practicing segmental and suprasegmentals, as well as comment on the problems they encounter when working on phonetics and the solutions devised.

Since the primary audience of this preliminary version of the survey are English philology students who have reached at least an upper-intermediate proficiency level, or B2 in terms of the Common European Framework, both the instructions and all the items are worded in English. Still, in order to ensure that potential deficiencies in their target language knowledge will not prevent the respondents from answering open-ended questions, commenting on each of the categories or precisely expressing their thoughts and feelings, it is explicitly stated in the introduction to the tool that English, Polish or both can be used for this purpose. As for the analysis of the responses, it involves a combination of quantitative and qualitative procedures depending on the nature of specific items. In the case of the former, the means are calculated for each Likert-scale item, each subscale and the whole inventory, with an eye to determining overall PLS use as well as the extent to which the respondents fall back upon different types of strategic devices. When it comes interpretation, Oxford's (1990) guidelines are followed, with the averages in the range of 5.0-3.5 indicating high strategy use, those in the range of 3.4-2.5 medium strategy use, and those in the range of 2.4-1.0 low strategy use. Also included in quantitative analysis is tabulating standard deviations for individual items, each subscale as well as the whole PLSS in order to determine the degree of variability among the respondents. As regards qualitative analysis, it involves identifying the recurring themes in the answers to the open-ended items and comments, although also in this case some kind of quantification is inevitable so as to pinpoint the most frequently mentioned ideas, issues or factors. Because of the fact that, similarly to the proposed taxonomy, the Pronunciation Learning Strategy Survey represents the outcome of work in progress and is likely to require a number of modifications pending the findings of ongoing research, a decision has been made not to include it in its present form in this publication.

\section{Pilot study}

According to Dörnyei (2003), the process of questionnaire design should consist of several clearly defined stages, namely: developing a pool of items, preparing the initial version of the instrument, piloting this first version, constructing the final version based on the results of the pilot study, and then validating the data collection tool by administering it to an appropriate sample of language learners. The objective of the study described in the present paper was to pilot the Pronunciation Learning Strategy Survey and thus it can be related to the first three phases of the questionnaire design process as envisioned by Dörnyei (2003), with the caveat that the procedures involved in coming up with the items and constructing the instrument were described in some detail in the preceding section. The participants were 80 English Department students in the second and third year of a BA program who could be described as quite proficient learners, had completed at least a year of pronunciation training, and had some background in foreign language pedagogy as well as descriptive grammar (i.e. phonetics and phonology). The 
rationale for the choice of the target group was that, because of the program and examination requirements, English philology students are naturally concerned about mastering various aspects of TL pronunciation, and thus they can be expected, first, to comprehend the questionnaire items and relate them to their own experiences, and, second, to reflect on their actions and thoughts and to provide a greater number of more valuable insights into PLS than less advanced respondents or those with little or no linguistic knowledge.

The survey was administered in the course of methodology classes, the students could take as much time as they wished to fill it out and, as pointed out above, they were free to choose the language in which they supplied their responses. The data collected in this way were then analyzed using the procedures discussed in the previous section, but, since the main aim of the study was to improve on the research tool, steps were taken to obtain information about its reliability and validity. These involved: (1) subjecting to close scrutiny the Likert-scale items in the four categories by using Corrected Item-Total Correlation (i.e. the inclusion of an item was reconsidered if the correlation between it and the subscale it belonged to was below 0.40) (Hatch and Lazaraton 1991; Kaplan and Saccuzzo 1993) and taking into account the comments included by the respondents, (2) determining the internal consistency reliability of the instrument by computing Cronbach Alpha for the whole inventory and each of the four subscales, and (3) establishing the validity of the survey by calculating its overall correlation with the Strategy Inventory for Language Learning. Additionally, qualitative analysis of the subjects' responses to the open-ended items concerning the ways of learning pronunciation served the purpose of identifying useful PLS that could have been omitted in the PLSS.

Even though the study provided insightful information about PLS use among advanced foreign language learners, it will not be reported here and the present discussion will only be confined to the data which are germane the evaluation of the research tool as such. When it comes to item analysis, it turned out that in the case of six of the Likert-scale statements the correlation coefficients proved to be below the established threshold of 0.40 (e.g. I listen to songs to improve my pronunciation, I use rhythmic gestures to accompany speech practice), whereas the wording of some others was somewhat ambiguous, as reflected in the comments included under the subscales (e.g. I practice pronunciation with other students, I preview the pronunciation features to be taught in class) which were incidentally rather infrequent. In addition, there was a visible overlap between some of the items, others appeared to be suitable for more than one category (e.g. I pay attention to teacher corrections of my pronunciation as I speak which can be interpreted as a metacognitive or cognitive strategy), and there were problems concerning the way in which the cognitive subscale was organized (i.e. grouping similar items together). When it comes to the reliability of the instrument, Cronbach Alpha coefficients amounted to 0.74 for metacognitive PLS, 0.64 for the cognitive PLS, 0.70 for the affective PLS, and 0.67 for the social PLS, with the mean for the entire PLSS standing at 0.69. As for the correlation between the average mean for the Likert-scale items and that for the SILL that the participants were requested to complete as part of another research project, it turned out to be positive and statistically significant, although rather moderate $(r=0.45 ; p<.05)$. Finally, the analysis of the responses to the open-ended items yielded some instances of pronunciation learning strategies that were not included in the survey (e.g. using computer software and Internet 
resources to practice aspects of pronunciation), showed that the decision to exclude compensation strategies (e.g. using proximal pronunciation) might have been premature, and indicated that it is warranted to give more weight to strategy chains (i.e. sets of related, mutually supportive PLS). When we examine the findings concerning the use of specific PLS, which will not be dealt with here in detail for reasons spelled out above, it should be noted that there was a close fit between the responses Likert-scale and openended items, since the use of traditional cognitive strategies was reported the most often, an outcome that is consistent with the results of previous research (e.g. Droździał-Szelest 1997; Petersen 2000; Pawlak 2008a).

The conclusions that can be drawn from this analysis are the following: 1) the PLSS is a research instrument that holds considerable promise for future study of pronunciation learning strategies and (2) there is a pressing need to modify the instrument taking into account the findings of this pilot study and subsequent research projects in which it will be employed. Among the positive outcomes of the evaluation we can mention the fact that most of the items turned out to be successful in tapping the use of the PLS, the values of correlation coefficients reflecting its reliability and validity are respectable, even if not very high, a number of new strategies were pinpointed and qualitative analysis confirmed to a large extent the overall outcomes of quantitative analysis. At the same time, however, there are reservations about the inclusion, wording, grouping or sequencing of some of the Likert-scale items, there might be a need to introduce the subscale of compensation strategies or at least add relevant items to one of the existing categories, it may be necessary to explicitly encourage the respondents to report the use of strategy chains, and Cronbach Alpha coefficients for some of the subscales are not fully satisfactory. While circumspection should be exercised about adding, deleting or rewarding specific items, some changes are clearly indispensible as is the need for further validation of the tool with a more sizable group of learners, thus completing the questionnaire design process recommended by Dörnyei (2003).

\section{Conclusions and implications}

The development of a comprehensive taxonomy of pronunciation learning strategies and the construction of a research tool that can supply data about their application is undoubtedly an important step that is likely to considerably advance this somewhat neglected line of inquiry. This is because it enables researchers to move beyond mere identification and descriptions of PLS and design studies that would aim to investigate the use of these strategies in different groups of learners, determine the relationship between strategic learning and proficiency, look at the variables affecting PLS choice and use, and ultimately examine the effects of strategies-based instruction in this area. Equally significant is the fact that it provides a so-much-needed point of reference, which facilitates making principled comparisons between different studies and furthering our understanding of the process of learning pronunciation in a more coherent way. On the other hand, such enthusiasm should be tempered in view of the fact that it is only the first step on the long path to drawing up a classification of the actions and thoughts that learners indeed resort to when learning pronunciation and coming up with valid and reliable ways of accurately measuring the use of such strategic devices. For one thing, 
there is much room for improvement both in the case of the proposed categorization and the data collection instrument, since the former is only a framework in need to extension and refinement whereas the pilot study reported above goes only part of the way in the process of survey design. Even when the validation of the tool has been completed, there will be a need to use it with learners representing other ages, proficiency levels or educational stages, which is bound to necessitate making further adjustments and perhaps constructing different versions of the PLSS. It should also be borne in mind that even a perfectly constructed questionnaire is bound to suffer from inherent weaknesses (cf. Dörnyei 2007), not least because it may fail to accurately reflect the existing reality and it provides only a static and often decontextualized snapshot thereof. For this reason, it is recommended to use methodological triangulation, which means that the data obtained by the PLSS or similar tools should be complemented through other instruments, such as task-specific surveys, interviews or diaries (cf. White et al. 2007; Pawlak 2009b). Lastly, given the distinctiveness of the sound systems of different languages, it might make sense at some point to develop language-specific inventories of PLS as well as accompanying research tools, although this is perhaps not the most urgent challenge. To conclude, research into pronunciation learning strategies is a promising line of inquiry that should be much more vigorously pursued by researchers in Poland and abroad than have thus far been the case.

\section{References}

Anderson. N. 2005. “L2 learning strategies”. In Hinkel, E. (ed.) 2005. 757-771.

Arabski, J. and A. Wojtaszek (eds.). (in press). The acquisition of L2 phonology. Clevedon: Multilingual Matters.

Berkil, G. 2009. A closer look at pronunciation learning strategies. Saarbrucken: VDM - Publishing.

Bukowski, D. 2004. "On the training of metacognitive and socio-affective strategies some implications for teaching and learning English phonetics". In Sobkowiak, W. and E. Waniek-Klimczak (eds.). 20-27.

Celce-Murcia, M. (ed.). 2001. Teaching English as a second or foreign language. Boston: Heinle \& Heinle.

Cohen, A. D. 1998. Strategies in learning and using a second language. London: Longman.

Cohen, A. D. and Z. Dörnyei. 2002. "Focus on the language learner: Motivation, styles and strategies". In Schmitt, N. (ed.). 2002. 170-190.

Cohen, A. D. and E. Macaro (eds.). 2007. Language learner strategies: Thirty years of research and practice. Oxford: Oxford University Press.

Cohen, A. D. and A. Pinilla-Herrera. 2009. "Communicating grammatically: Constructing a learner strategies website for Spanish". In Kao, T. and Y. Lin (eds.). 63-83.

Dörnyei, Z. 2003. Questionnaires in second language research: Construction, administration and processing. Mahwah, NJ: Lawrence Erlbaum.

Dörnyei, Z. 2005. The psychology of the language learner: Individual differences in second language acquisition. Mahwah, NJ: Erlbaum. 
Dörnyei, Z. 2007. Research methods in applied linguistics: Quantitative, qualitative and mixed methodologies. Oxford: Oxford University Press.

Droździał-Szelest, K. 1997. Language learning strategies in the process of acquiring a foreign language. Poznań: Motivex.

Eckstein, G. T. 2007. "A correlation of pronunciation learning strategies with spontaneous English pronunciation of adult ESL learners". MA thesis, Brigham Young University. (http://contentdm.lib.byu.edu/ETD/image/etd1973.pdf).

Ellis, R. 2005. "Measuring implicit and explicit knowledge of a second language: A psychometric study". Studies in Second Language Acquisition 27. 141-172.

Ellis, R. 2008. The study of second language acquisition. (second edition). Oxford: Oxford University Press.

Ellis, R. 2009. "Implicit and explicit learning, knowledge and instruction". In Ellis, R., S. Loewen, C. Elder, R. Erlam, J. Philp and H. Reinders (eds.). 2009. 3-25.

Ellis, R., S. Loewen, C. Elder, R. Erlam, J. Philp and H. Reinders (eds.). 2009. Implicit and explicit knowledge in second language learning, testing and teaching. Bristol Buffalo - Toronto: Multilingual Matters.

Goodwin, J. 2001. “Teaching pronunciation”. In Celce-Murcia, M. (ed.). 2001. 103-116.

Grenfell, M. and Macaro, E. 2007. "Claims and critiques". In Cohen, A. D. and E. Macaro (eds.). 9-28.

Griffiths, C. 2008a. "Strategies and good language learners. In Griffiths, C. (ed.). 2008b. 83-98.

Griffiths, C. (ed.). 2008b. Lessons from good language learners. Cambridge: Cambridge University Press.

Hatch, E. and A. Lazaraton. 1991. The research manual. Boston, MA: Heinle \& Heinle.

Hinkel, E. (ed.). 2005. Handbook of research in second language teaching and learning. Mahwah, NJ: Lawrence Erlbaum.

Kao, T. and Y. Lin (eds.). 2009. A new look at language teaching and testing: English as subject and vehicle Taipei, Taiwan: The Language Training and Testing Center.

Kaplan, R. M. and D. P. Saccuzzo. 1993. Psychological testing: Principles, applications and issues. (fifth edition). Belmont, CA. Wadsworth.

Kelly, G. 2000. How to teach pronunciation. Harlow: Pearson Education.

Kolb, D. A. 1984. Experiential learning: Experience as the source of learning and development. Englewood Cliffs, NJ: Prentice Hall.

Macaro, E. 2001. Learning strategies in foreign and second language classrooms. London: Continuum.

McDonough, S. H. 1995. Strategy and skill in learning a foreign language. London: Edward Arnold.

Naiman, N., M. Fröhlich, H. H. Stern and A. Todesco. 1996 (1978). The good language learner. Clevedon: Multilingual Matters.

Nijakowska, J. (ed.). 2010. Interdyscyplinarne studia nad świadomościa $i$ przetwarzaniem językowym. Kraków: Tertium.

O'Malley, J. M. and A. U. Chamot. 1990. Learning strategies in second language acquisition. Cambridge: Cambridge University Press.

O’Malley, J. M., A. U. Chamot, G. Stewner-Manzanares, R. P. Russo and L. Küpper. 1985. "Learning strategy applications with students of English as a second language”. TESOL Quarterly 19. 285-296. 
Osborne, A. 2003. "Pronunciation strategies of advanced ESOL learners". IRAL 41. 131143.

Oxford, R. 1990. Language learning strategies: What every teacher should know. Boston, MA: Heinle.

Pawlak, M. 2006a. "On the use of pronunciation learning strategies by Polish foreign language learners”. In: Sobkowiak, W. and E. Waniek-Klimczak (eds.). 2006a. 121135.

Pawlak, M. 2006a. "The role of learner autonomy in pronunciation instruction". In Sobkowiak, W. and E. Waniek-Klimczak (eds.). 2006a. 131-143.

Pawlak, M. 2008a. "Another look at pronunciation learning strategies: An advanced learner's perspective”. In Waniek-Klimczak, E. (ed.). 2008. 304-322.

Pawlak, M. 2008b. Investigating English language learning and teaching. Poznań Kalisz: Adam Mickiewicz University Press.

Pawlak, M. 2009a. "Investigating grammar learning strategies: In search of appropriate research tools". Paper read at 19th Annual Conference of the European Second Language Association, Cork, Ireland.

Pawlak, M. 2009b. "Metodologia badań nad strategiami uczenia się". Neofilolog 32. 6583.

Pawlak, M. 2010a. "Teaching foreign language pronunciation: Issues in research focus and methodology". In Waniek-Klimczak, E. (ed.). 2010. 169-183.

Pawlak, M. 2010b. "Strategie uczenia się gramatyki - próba klasyfikacji". In Nijakowska, J. (ed.). 2010. 97-116.

Pawlak, M. (in press). "Students' successes and failures in learning foreign language pronunciation: Insights from diary data". In Arabski, J. and A. Wojtaszek (eds.). (in press).

Peterson, S. 2000. "Pronunciation learning strategies: A first look". Unpublished research report. (ERIC Document Reproduction Service ED 450 599, FL 026 618)

Reiss, M. A. 1981. "Helping the unsuccessful language learner". Modern Language Journal 65. 121-128.

Rivers, W. 1979. "Learning a sixth language: An adult learner's daily diary”. Canadian Modern Language Review 36. 67-82.

Schmitt, N. (ed.). 2002. An introduction to applied linguistics. London: Arnold.

Sobkowiak, W. and E. Waniek-Klimczak (eds.). 2004. Dydaktyka fonetyki języka obcego $w$ Polsce. Zeszyty Naukowe Państwowej Wyższej Szkoty Zawodowej w Koninie 1/2004. Zeszyt Naukowy Instytutu Neofilologii 3. Konin: Wydawnictwo Państwowej Wyższej Szkoły Zawodowej w Koninie.

Sobkowiak, W. and E. Waniek-Klimczak (eds.). 2006a. Dydaktyka fonetyki języka obcego w Polsce. Konin: Wydawnictwo Państwowej Wyższej Szkoły Zawodowej w Koninie.

Sobkowiak, W. and E. Waniek-Klimczak (eds.). 2006b. Dydaktyka fonetyki języka obcego II. Zeszyty Naukowe Państwowej Wyższej Szkoły Zawodowej w Plocku. Neofilologia Tom VIII. Płock: Wydawnictwo Państwowej Wyższej Szkoły Zawodowej w Płocku.

Takeuchi, O., Griffiths, C. and Coyle, D. 2007. "Applying strategies to contexts: The role of individual, situational, and group differences". In Cohen, A. D. and E. Macaro (eds.). 2007. 69-92. 
Varasarin, P. 2007. "An action research study of pronunciation training, language learning strategies and speaking confidence", Ph.D. dissertation, Victoria University.

(http://wallaby.vu.edu.au/adt-VVUT/uploads/approved/adtVVUT20070911.162030/public/01 front.pdf)

Vitanova, G. and A. Miller. 2002. "Reflective practice in pronunciation learning". The Internet TESL Journal 8/1.

Waniek-Klimczak, E. (ed.). 2008. Issues in accents of English. Newcastle upon Tyne: Cambridge Scholars Publishing.

Waniek-Klimczak, E. (ed.). 2010. Issues in accents of English 2: Variability and norm. Newcastle upon Tyne: Cambridge Scholars Publishing.

Wenden, A. 1991. Learner strategies for learner autonomy. London: Prentice Hall.

White, C., K. Schramm and A. U. Chamot. 2007. "Research methods in strategy research: Re-examining the toolbox”. In Cohen, A. D. and E. Macaro (eds.). 2007. 93-116.

Wrembel, M. 2008. "In search of effective strategies for L2 pronunciation teaching and learning”. In Pawlak, M. (ed.). 2008b. 179-194. 